\title{
LEGAL ASPECTS OF PARENTAL RESPONSIBILITY IN THE EDUCATION OF A CHILD
}

\author{
Rihards Erdmanis \\ Rīga Stradiṇš University, Latvia
}

\begin{abstract}
In the Latvian education system, the legal relationship between parents and the school is important. The child's parents are obliged to take the child to school. It means that the State implements an education policy in line with both the findings based on educational science and that the child's right to education is ensured at least at the basic school level. In Latvia, education law as a branch of law is an underdeveloped field. The legal relationship between children's parents and the educational institution has been little studied from the legal science perspective. Thus, in this study, the author analyzes the role of the institute of parental responsibility in the field of education, using the methods of interpretation of general science and law - historical, grammatical and teleological methods. It is found that the special legal regulation of Latvia determines specific parental responsibilities and rights in providing education for their child. Teachers do not become substitutes for the child's parents, but have a duty to do so as responsible and caring parent would do to their children. Parental authority does not end when the child enters the school premises, but it is limited to the extent that the educational institution fulfills its responsibilities by ensuring an educational process in accordance with the child's interests and human rights.
\end{abstract}

Keywords: education law, family law, parental authority, parental responsibility, public and private power, teacher's rights and duties.

\section{Introduction}

A child's education is necessary for his/her development. Namely, education alongside the child's health, emotional and behavioural development, identity, family and social relationships, and self-care skills is an essential need for the child's development (The Children guidance and regulations Act, 2015). Education is a long-term, continuous, systematic process, which means that it can be analyzed in its time, system and development dimension. For instance, education is the process and result of the acquisition of systematized knowledge and skills and the formation of attitudes. The educational process includes learning and upbringing activities, but the outcome of education is a set of personal knowledge, skills 
and attitudes. The Latvian Constitutional Court points out that the quality, accessibility and content of education at all levels and age groups of education is an opportunity for Latvia's development and a precondition for increasing the value of human capital (The Constitutional Court of the Republic of Latvia, 2019). A similar view is expressed by the United Nations Educational, Scientific and Cultural Organization (UNESCO), which points out that it is generally accepted that formal education is one of the most important factors in contributing to an individual's skills and human capital, although it is not the only factor. Namely, parents, individual abilities and other people contribute to the child's schooling. For a long time, the child's parents have not been left indifferent to what is happening in the education system and at school. Jan Amoss Komensky, the author of the $17^{\text {th }}$ century classic work of pedagogy - "Great Didactics" - considered that the work of education and cultural care is the most important duty of every civilized country, but the child's education begins at home, that is in the so-called "mother's school" where education is undertaken by the child's parents (Komensky, 1632/1992). Positive cooperation between school and family based on mutual respect is one of the most important preconditions for the development of a student's personality (Klauža et al., 2009). Already, in the 1930s, Latvian legal scholar Vasilijs Sinaiskis pointed out that civil society tries to highlight a person's personality, but in the past, personality was suppressed in society for the benefit of the general public. He emphasizes that the scale of civil society is determined by its limits. This means highlighting the individuality of the personality, promoting sociability and weakening social antagonism. Thus, with the help of legal norms, it is possible and even necessary to promote the general development of culture and personality, reduce social contradictions and promote the involvement of the individual in the processes of society. Undoubtedly, socialization helps an individual to acquire social norms, including legal norms, to become an educated person, and it in turn encourages easier adaptation or integration into society and finding one's place in it, as well as developing one's talents, abilities, skills and competences, and spiritual potential. The process of upbringing is possible if a person is considered to be a subject of social development, a subject of life, culture, creativity and production. Namely, the pedagogical scientist Jurgena points out that the personality must be seen as a dynamic formation and special attention must be paid to its determination. In her opinion, the determinants of personality development are the peculiarities of age, socio-psychological and psychological characteristics and complex structural procedural interrelationships in their interaction (Jurgena, 2002). It is believed that the school learning process should promote the formation of harmonious and strong personalities (Belickis et al., 2000). In turn, the child's parents, 
as the child's natural guardians (legal representatives), have a duty to protect the child's rights and interests protected by law, including the right to education (Law on the Protection of the Rights of the Child, 1998). The Latvian Education Law imposes one of the following obligations on parents - to observe the legal rights and interests of children, teachers and other persons (Education law, 1998). Respectively, parents have a duty to respect their legal rights and interests. The right to education as a subjective right means that: a) the right to education is legalized for all without any discrimination; (b) the State has an obligation to respect, protect and exercise these rights; (c) there are ways in which the State can be held liable for the abuse or denial of this right. Thus, the State has the right and obligation to ensure that the new generation receives education and its implementation is adequately protected, but the child's parents have an obligation to ensure that the child receives education. In order to gain clarity on parental responsibility in the field of education, it is necessary to clarify what is determined in both national and international legislation on the role and functions, power and responsibility of the child's parents in the field of education. Researchers of the Latvian education system point out that teachers feel a violation of their rights by students and students' parents (Berage, 2020). Teachers, in cooperation with parents, see difficulties both in terms of psychology and in separating the responsibilities of parents and teachers. In the author's opinion, it is necessary to analyze such categories as "parental responsibility", "parental authority" with the methods of interpretation available in law, and to find out what is said in Latvian legal doctrine for determining parental responsibility for the education and upbringing of one's child.

\section{An insight into the history of the institute of parental authority}

Būmanis, a Latvian legal scholar and editor of the Latvian Civil Law of 1937 translates the term "parental authority" from Latin as "patria potestas", Russian as "родительская власть", and German as "elterliche Gewalt". He points out that the oldest textbook of Roman law "the Institutes of Gaius", which was written in the $2^{\text {nd }}$ century, in it is stated: “..Follows another division of rights of persons. Namely, some persons have their own rights, others are subject to foreign rights. However, among the persons subject to foreign rights, some are in the power of the master or father (potestas), others in the power of the husband (manus), still others in the service of mancipium - the status of a freeman subject to the power and control of the head of a Roman family similar to that of a slave except that he could not be abused or killed without legal cause. The Latin term "patria potestas "means" power of the father (Būmanis, 1937). In Roman 
law neither a woman nor child are considered to have a certain amount of rights and obligations, which means that they do not have the ability to express their will. In ancient Rome, a man was considered a person. Only later the person was every person, both persona sui iuri (having full legal rights or capacity) and persona alieni iuris (to be legally dependent upon the power of another) (Sinaiskis, 1938). In the author's view, this circumstance could also indicate that a man who has become a father therefore has enormous power over his wife and children, because quite naturally, if they are not subjects of law, then they are not equal in the status of expressing their personal will.

Professor Vasilijs Sinaiskis points out that in the Latvian Civil Law the term "parental power" is retained, abolishing the term "husband's power", which was used before 1937. Namely, it emphasized the principle of equality of spouses. At the same time, the term 'parental authority' is retained, meaning that parents have power over the child until he or she reaches the age of majority (18 years old). The meaning of the institute of parental authority, on the other hand, is based on the welfare of the minor, but no longer only on parental rights, and parental authority is more a duty than a right. Should a child not have the ability to act, then this ability is organized as another person's ability for the benefit of the child - in the form of guardianship. When legal capacity is analyzed from this point of view, then it cannot be said that representation is a child's ability. However, this is a fiction, because an alien ability can never be a child's ability. In this case, it is not a question of ability, but of opportunity. Consequently, legal capacity is a legal term, but in fact it is a legal possibility (Sinaiskis, 1938). We have no evidence that the father has had the power to take the lives of his disobedient children, but he has been able to exclude them from the right of inheritance. Švābe (1932) stated, "Which was sometimes expressed in the threat formula: "I will not give him needles without an eye." (p. 21). The son, who resisted his father's power, was driven into the woods to begin the procession. (Švābe, 1932). Thus, the ancient Latvian traditions define the belief that children must obey their parents, that is Latvian traditions determine to honour parents, at least because they are older and wiser than children. Thus, it can be seen that in Latvian traditions there is an institute of parental power or the right to demand obedience from children. The absolute power of parents over their children can be found in both Ancient Greece and Ancient Rome. Namely, the family does not acquire its rights from an organized community or civil society (Latin-civitas). This is the view of the French historian Fustel de Coulanges. He points out that if private law were governed by civil society, or civitas, it would probably be very different from what we see today. De Coulanges emphasized that in such 
a case, for example, civil society's (civitas) property rights and inheritance rights would be based on completely different grounds, as it was not in its interest to make land inseparable and kinship inheritance inseparable. The law that legitimized the father's right to sell or even kill his son is found in both Ancient Greece and Ancient Rome (de Coulanges, 1864/2017). It can therefore be concluded that private law takes precedence over public law. Consequently, they had a significant impact on family law, that are the norms and procedures of the family. At the same time, Professor Kalnins points out that from the point of view of practice, Roman family law is not valid in any world legal system today. That is, from this point of view, Roman law is history or a historical fact (Kalnins, 1938). Sinaiskis, on the other hand, points out that not only the family, but also the whole political organization was different than it is today. Roman family law was based on the principle of power, where the head of the family - pater familias (the father of the family) and his power was absolute, unlimited. The other members of the family are fully subordinate to this power and are considered alien iurs-persons without their own rights. The principle of kinship that characterizes the modern family was not the basis of the Roman family. The emancipated son was no longer a family member and therefore no longer a relative, but a complete stranger. The father had no power over the son, but on the contrary a stranger who was part of the family farm was under the power of pater familias. Namely, in the beginning this power was a physical, material power. The power that belongs to a soldier, but over time this absolute power diminished and instead another term arose - potestas, which describe the legal power of the head of the family, the possibility of doing or not doing something (Sinaiskis, 1938). As previously emphasized, there has long been a custom in the Latvian family that the father is the head of the family, although, as has already been pointed out, the father did not have such unlimited power over the children. Namely, a child could not be sold (son) or even killed, but in ancient Rome or Greece it was legally justified and allowed. Sinaiskis points out that Roman law as a permanent system of positive rights and their influence in Latvian legal system is extremely great. That is, the Latvian Civil Law of 1937 in most is based on Roman law. Namely, this applies in particular to the law of obligations and property, but many important institutes and principles of Roman law have not been completely abandoned in family and inheritance law either (Sinaiskis, 1938). Thus, as indicated above, the term "parental authority" in the Latvian Civil Law essentially emphasizes that parents have a duty to take care of them, but in order to take care of their children, parents need some authority. In this sense, the expression of power would be in the right of the parent. That is, it is a subjective right that belongs to a particular individual. Namely, it is 
a parent's subjective right (power), which belongs to it as a subject of rights on the basis of objective law - general law. In this case, the parental right (power) is expressed as the will of the parents, because the right is based on the will, but in order for a person to settle a relationship with his or her own will, the law must give him or her certain rights-power. It can be seen that the above-mentioned concept of the connection of parental authority with the obligation to care for a child under its control is a historically developed concept. This aspect is important because it emphasizes that parents are not and cannot be just holders of power, but also that parents have both rights and responsibilities. Thus, the absolute expression of the above-mentioned father's power was rooted in tradition or custom, and originally existed in private law, i.e. long before the ancient Romans, as an organized society or group of citizens, created so-called public law and only as a result of long-term development. From the author's point of view, it is important to be aware of the further analysis of the legal relationship between an educational institution as a public authority (a subject of public law) and parents as a subject of private law. Namely, it could be assumed from the above that family life and the order that has prevailed in it for a long time is unshakable and inherently inviolable. From the point of view of $21^{\text {st }}$ century legal science, it must be concluded that parental power or rights are not absolute rights. The author can conclude from the above prima facie (at first sight) that the parents have a certain power in the upbringing of their child, which means that the parent is entitled to use it not with abuse or violence, but with a certain sense of duty. For example, taking care of a child so that he or she can both eat and acquire knowledge and skills that will be useful in the child's future life.

Article 177 of the Latvian Civil Law (Civil Law, 1937) stipulates that a child is under parental custody until reaching the age of majority (in Latvia a person is generally a minor under 18 years of age) and that custody is the parental right and duty to care for the child and his or her property and represent the child in his or her personal and property relations. That is to say, until the child has reached the age of majority, the child is in the custody of their parents. In this connection, it should be noted that in the 1930s, when the Latvian Civil Law was adopted, the first version indicated that during marriage both parents exercised their parental authority over their children jointly. Should there have been a disagreement between them, the voice of the arbitrator belongs to the father. Should the mother be convinced that the father's will and actions over the children are bad for the latter, she can ask the orphan's court to invite the father to change his will or actions. Should the orphan's court deem it necessary, the Court could entrust the upbringing of the children only to the mother. It is the duty of parents to take care, in proportion to 
their property and social situation, of the well-being of their children, to provide them with accommodation, to provide them with food, clothing, care, upbringing and education. As can be seen, although the Latvian Civil Law stipulated that parenting may be exercised jointly and severally by both parents, at the same time the child's father is given the right to have the final word, i.e. if a dispute arises, the father has the right to have the final word. The author believes that this is the so-called anachronism that has survived from Roman law, because, as has already been emphasized above, the power of father or husband to the ancient Romans is absolute. However, the role of the mother in the Latvian law of 1937 is emphasized by the fact that she has the right to disagree with the will of the father. It can be seen here that family relationships began to change from narrowly private to public, for instance, the child's mother has the right to apply to an orphan's court if she does not agree with the father's will. The Supreme Court of the Republic of Latvia (Senāts) points out that custody must be understood as a set of parental rights and responsibilities in the broadest sense, which includes other, narrower concepts - joint custody, daily custody, separate custody, care, supervision, rights of access (The Supreme Court of the Republic of Latvia, 2012).

The Latvian Civil Law has long paid special attention to the interests of children, because they did not belong only to parents and were not created for their pleasure. Latvian legal scholar Konstantīns Čakste (1937/2011) also points out that parental power is not based on the idea of power, but on the idea of guardianship. Namely, that parental power is only a means of performing parental responsibilities. The Latvian Civil Law introduced the modern idea of law of its time, i.e., the idea of State control. At the same time public authorities had a duty and a right to monitor the exercise of the rights of parents. In addition to the above, it is necessary to find out to what extent the state with its institutional system is entitled to interfere in the power of parents. Namely, the author assumes that the parents were responsible for the child's upbringing and education, but the State supervised this process, that is controlled how the parents exercised their power arising from its natural status. Thus, it would be necessary to analyze in more detail the scope of parental responsibilities and rights, that is parental responsibility, as well as the responsibility of the State for the upbringing and education of a child. In this regard, attention must be paid to the concept of parental responsibility in an educational context.

\section{Parental responsibility and education context}

In the author's opinion, the observation in the practical application of parental responsibility and duties is controversial, that is it is difficult to 
draw the line between parental and state responsibility in practice. For example, the United Nations (UN) Global Education Monitoring Report $2017 / 18$ states that the primary responsibility of teachers is to provide highquality education, but at the same time, teachers are expected to do much more than provide education. In turn, the main responsibility of parents, according to the UN, is to ensure that the pupil attends school at least at the level of primary education, and that parents should be responsible for the child's behavior. Students' responsibility for their behavior increases with each passing year as they become parents (UNESCO, 2018). Thus, it can be seen that parental responsibility for the child's education (in this case, the author understands education both as a process and as a result) is mutual. Namely, on the one hand, parents are the ones who should take care that the child receives an education at least at the primary school level, but teachers have a responsibility to ensure that the quality of education guaranteed by the State is of a high quality. At the same time, the teacher should be much more responsible than just for the quality of education. One of the teacher's skills is the ability to cooperate with parents, and actively participate in the development of their child-student (Ancāne et al., 2014). Therefore, in the author's opinion, it is necessary to go into the content of parental responsibility. In this way, the responsibility of one of the most important implementers of educational rights - the parents of the child would be clarified. Legal scholar Yosi Yaffe points out that the concept of parental authority forms a two-dimensional theoretical construct - power and legitimacy. It consists of four main aspects:

(a) parental authority and the potential impact on the child's behavior;

(b) the legal authority of the parents, which means the right of the parents to request and the child's duty to obey, to submit to the demands of the parent. Parental authority manifests itself as a conflict between a parent and a child (contradiction, disagreement), but at the same time it varies depending on the child's age and the context in which it appears (Yaffe, 2013).

Article 1 (2) of the Hague Convention on Jurisdiction, Applicable Law, Recognition, Enforcement and Cooperation in Respect of Parental Responsibility and Measures for the Protection of Children states that the term "parental responsibility" is used in this Convention is a parental authority or other similar relationship of responsibility which determines the rights, powers and responsibilities of parents, guardians or other legal representatives in relation to the person or property of the child. British child rights experts point out that the term 'parental responsibility' focuses on parental responsibilities towards the child and not on parental rights in relation to the child (Convention, 1996). For example, it is the responsibility of parents to make decisions about their child. These decisions include 
determining the child's education and which school the child will attend, choosing the child's name, in the event of parental death, appointing a guardian for the child, consenting to the child's treatment, allowing the child's medical records, allowing the child to go abroad, representing the child in legal proceedings, as well as the determination of the child's religious affiliation (Child law advice, 2020). The author sees a similarity between the content of the concept of parental responsibility or power in the Anglo-Saxon legal system and the content of parental power or responsibility found in the Romano-Germanic legal system. UK legal scholar Rachel E. Taylor points out that the way in which a country responds to the question of the role of parents and state in children's religious upbringing and education will inevitably reflect the history, constitutional foundations, and prevailing social conditions within the state (Taylor, 2015). For instance, the Civil Law of the Republic of Latvia states that parents have the right to determine a child's surname. That is, Article 151 of the Latvian Civil Law provides: "The surname of a child is determined by the surname of the parentsshould the parents have different surnames, the child shall be given the father's or mother's surname by agreement. Should the parents not agree on the child's surname, it shall be determined by a decision of the Orphan's Court (Civil Law, 1937). As can be seen, under Latvian law, parents are responsible for the choice of a child's surname, but if the parents are unable to agree, then this responsibility or duty is authorized by the Orphan's Court. Thus, it can be seen that parental responsibility or power is not absolute, as it is limited by a certain element of State or civil power. That is, the Orphan's Court as a bearer of public power is delegated to act in the best interests of the child, which means that the child's right to individuality (the child's right to individuality is defined in the Latvian Law on the Protection of Children's Rights) is exercised by the Orphan's Court. Parents have the right and power to decide which educational institution the child will attend. Such parental rights are specified in Section 57, Paragraph 1 of the Latvian Education Law (1998). Namely, this law stipulates that one of the parents' rights is to choose the educational institution where the child receives education (Education law,1998). In the legal relationship between the parents and the educational institution, arises question whether the school is instead of parents or takes the parents role. In that regard, it is necessary to refer to the doctrine in loco parentis (instead of parents). Marcus Fabius Quintilianus (Latin for Marcus Fabius Quintilianus), one of the most prominent orators in ancient Rome, who was also the most famous lawyer of his timepoints out in his book Institutio oratoria (On the Education of an Orator) that the teacher must play the role of parent to his students (Quintilianus,trans 1974). It can be seen that the idea that not only the child's biological 
parents are responsible for the child's upbringing and education, but also other adults, such as teachers, can and should be responsible for the children entrusted to them. Legal scholars of the Anglo-Saxon law Alan Hall and Margaret Hanina point out that this concept remains important from an ethical point of view, as it emphasizes the duty of care. Namely, the teacher's professional duty is to take care of his students or those under his supervision (Hall \& Hanins, 2001). Although in loco parentis is not used directly in university or college or school programs, at the same time it has a background role in discussing the relationship between students and the educational institution. Hence, creating a perspective in this relationship. It can be seen here that the representatives of the Anglo-Saxon law in loco parentis associate the fact that parents as well as teachers have to take care of the child's well-being, but in order to do so, both the teacher and the parent need authority. The teacher, for example, needs to discipline students, but in order to achieve discipline, it is necessary that the teacher is endowed with some power (Merrick, 2016). The European Court of Human Rights (Kilkelly, 2001) emphasized that the school discipline system is considered to be within the scope of the right to education. In particular, the following conclusion follows from Article 28 (2) of the United Nations (UN) Convention on the Rights of the Child (Convention on the Rights of the Child, 1989). Both parents and teachers must use their power in a way that respects human rights. The rights of the child may not be violated on the grounds that the child is a person under the authority of the school. That it is not enough for the State to create an education system and to declare the right to education, but the State has an obligation to take responsibility for not violating either national or international law. In the Latvian legal system, the term in loco parentis is not directly used, but its content can be presumed from legal acts. The limiting element of parental authority was presented in Part III of the Compendium of Baltic Local Laws (Code of local legalizations of the Ostsee provinces Part III, 1864). Parental authority does not end, but is limited when children enter public school, to the extent that the public authority (school staff) takes the place of the parents in the upbringing and education of a child. It means that school staff have an obligation and the right to be responsible for the safety, health, development and education of a child, as a responsible parent would be. The teacher is not a substitute of parental power, i.e. they do not overwhelm the power of parents. This aspect is important as much as it describes the extent of rights and obligations of a rightholder who stands instead of parents (in loco parentis). Parents do not lose their power over the child, but it is limited until the pupil leaves the school or school event. 


\section{Discussions and Conclusions}

The Constitutional Court of Latvia indicated that in the legal relations affecting the child and in all activities regarding children, the rights and interests of the child is the priority. This means that not only the court but other institutions must take their decisions on the basis of what is in the best interests of the child (The Constitutional Court of the Republic of Latvia, 2004). In this connection, the best interests of the child include the right to education. In turn, the acquisition of education is unthinkable without the cooperation of parents and the educational institution. It is concluded that cooperation between parents and the school is important because it improves the quality of education, as well as is the basis for guaranteeing the right to education. The education system is not only influenced by the country's political or economic system. It is also influenced by the legal system and the legal framework. The author points out that the authority and responsibility of the child's parents remain even when the child attends an educational institution. Although the legal aspects of the responsibility of an educational institution and parental responsibility are controversial, at the same time Latvian legislation determines the duties and responsibilities of parents in the education of a child. It is concluded that parental authority does not diminish from the moment a pupil arrives at school, it is only limited to the extent that the educational institution exercises its rights and obligations, which are set out, for example, in the Education Law (1998). For instance, the scope of teachers and parents' rights and obligations in the field of education is regulated by a special law, i.e. the Education Law (1998). In its turn, the Latvian Civil Law (1937) as a general law determines the obligation of parents to take care of the child's education and upbringing. It should be noted that the teacher does not take the place of the parent, but at the same time it is the teacher's duty to carry out his/her professional activity even as carefully and responsibly as a caring and responsible parent would do for his/her child. Further scientific discussion would be needed, analyzing the specific responsibilities of parents and teachers if, for example, a student systematically violates the school's internal rules or endangers the safety of himself or herself and other students.

\section{References}

Ancāne, G., Ancāns, A., Miksons, A., Remese, I. (2014). Ieteikumi psihologiem un pedagogiem darbam ar skolēniem, kuriem ir uzvedïbas traucējumi skolas vidē [Recommendations for psychologists and educators to work with students with behavioral disorders in the school environment] Riga: Slimības profilakses un kontroles centrs [Center for Disease Prevention and Control]. 
Berağe, B. (2020). Pedagogu profesija Latvijas izglītibas sistēmā un tai piederošās tiesībās. Magistra darbs [Teachers' profession in the Latvian education system and its rights, Master's Thesis]. Latvijas Universitāte. Retrieved from dspace.lu.lv.

Belickis, I., Blūma, D., Koḳe, T., Markus, D., Skujiṇa, V., Šalme, A. (2000). Pedagoơijas terminu skaidrojošā vārdnīca [Glossary of pedagogical terms]. Riga: Zvaigzne ABC.

Broks, A., Buligina, I., Koķe, T., Špona, A., Šūmane, M., Upmane, M. (1998). Izglìtibas terminu skaidrojošā vārdnīca [Glossary of educational terms]. Riga: Latvijas pašvaldību mācību centrs.

Būmanis, A. (1937). Civiltiesibu terminologiijas vārdnīca [Glossary of civil law terminology]. Rìga: s.n.

Čakste, K. (2011). Civiltiesïbas [Civil law ]. Riga: Zvaigzne ABC. (Original work published 1937).

Child law advise. (2020). Parental responsibilty. Retrieved from: www.chlidlawadvise. org.uk.

Convention on jurisdiction, applicable law, recogniton, enforcement and co-operation in respect of parental responsibility and measures for protectection of children. (1996). Retrieved from: https://www.hcch.net/en/instruments/conventions/full-text/?cid=70.

De Coulanges, N. D. F. (2017). The Ancient City: A Study of the Religion, Laws, and Institutions of Greece and Rome (W. Small, Trans.). New York, NY: Dover. (Original work published 1864).

Education for all: the quality imperative; EFA global monitoring report. (2005). Retrieved from: https://unesdoc.unesco.org/ark:/48223/pf0000137333.

Hall, A. J. \& Manins, M. (2001). In loco parentis and the professional responsibilities of teachers. Waikato Journal of Education, 7, 117-128.

High Court of Latvia. (2012). Summary of case law on Disputes concerning custody (joint, separate, daily) and access rights and maintenance for a child. Retrieved from: at.gov.lv.

Izglīitibas likums. (1998). [Education law]. Riga: Latvijas Vēstnesis.

Judgment of the Constitutional Court (2019) in case no. 2018-15-01. Retrieved from: http://www.satv.tiesa.gov.lv.

Judgment of the Constitutional Court (2004) in case no. 2004-02-0106. Retrieved from: http://www.satv.tiesa.gov.lv/wp-content/uploads/2016/02/2004-02-0106_Spriedums. pdf.

Jurgena, I. (2002). Vispārīgā pedagoǵïa [General pedagogy]. Riga: Izglïtības soḷi.

Kalniņš, V. (1938). Romiešu tiesïbas [Roman law]. Riga: s.n.

Klauža, A., Kozaka, Dz., Pagraba, E., Smirnova, I., Veispale, K. (2009). Skolas un gimenes sadarbiba [School and family cooperation]. Retrieved from visc.gov.lv/audzinasa.

Kilkelly, U. (2001). The Best of Both Worlds for Children's Rights? Interpreting the European Convention on Human Rights in the Light of the UN Convention on the Rights of the Child. Human Rights Quarterly Johns Hopkins University Press, 308-326.

Komenskis, J. A. (1992) Lielā didaktika [The Great Didactic]. V. Grudulis, E. Klavniece, J. Rudzītis (Transl.). Riga: Zvaigzne. (Original work published, 1632).

Latvijas Republikas likums Civillikums. (1937). [Latvian Civil Law]. Riga: Valdỉbas Vēstnesis. 
Law on the Protection of the Rights of the Child of the Republic of Latvia. (1998). Riga: Latvijas V ēstnesis.

Merrick, R. M. (2016). Is it dead or alive? An Analysis of the doctrine and policy of in loco parentis at American universities. Available from ProQuest Dissertations \& Theses Global database. UMI No. 10188939.

Quintilianus, M. F. (1974). Institutio Oratoria (On the Education of an Orator), Vol. 1 (I. Butler Trans.). Twayne Publisher, Inc. (Quintilianus, trans. 1974).

Sinaiskis, V. (1934). Civiltiesïbas. Eksāmena jautājumi [Civil law. Exam questions]. Riga: A. Vilka izdevniecība.

Sinaiskis, V. (1938). Mūsu pienākumi un tiesības jaunajā Civillikumā [Our responsibilities and rights in the new Civil Code]. Riga: Litogr. Izd.

Sinaiskis, V. (1938). Romiešu tiesïbu sistēma [Roman legal system]. Riga: Litogr. Izd.

Švābe, A. (1932). Latviešu tautas tiesiskie uzskati [Legal views of the Latvian people]. Riga. Valters \& Rapa.

Sinaiskis, V. (1938). Romiešu tiesïbu sistēma [Roman legal system]. Rīga: Litogr. izd.

Taylor, R. E. (2015). Responsibility for the sof the child: The role of the state and parents in determining religious upbringing and education. International Journal of Law, Policy and The Family, 29, 15-35. doi: 10.1093/lawfam/ebu018.

United Nations Educational, Scientific and Cultural Organization. (2017). Global Education Monitoring Report (GEM Report). Retrieved from:www.unesco.org/ gemreport.

United Nations (UN) Convention on the Rights of the Child (1989). Retrieved from https://www.ohchr.org/en/professionalinterest/pages/crc.aspx.

UK Department for Education (DFE), corp creator. (2015). The Children Act 1989 guidance and regulations. Vol. 2, Care planning, placement and case review. Retrieved from http://dera.ioe.ac.uk/id/eprint/23448.

Yaffe, Y. (2013). "Parental authority": What do we know about the construct. Retrieved from: ttp://www.academeresearchjournals.org/journal/ijerd. 